\title{
【特 集：使用済自動車】
}

\section{使用済自動車の再資源化等に関する 法律案 (自動車リサイクル法案) の概要}

坂 川 勉 $*$

\begin{abstract}
【要 旨】わが国で年間約 500 万台排出される使用済自動車については，従来は，解体業者や破碎業者 が部品や金属などを回収するリサイクルシステムが有効であった。しかし，鉄スクラップ価格の低迷や， シュレッダーダストの処理費用の高騰などによって, 使用済自動車の価值が低下して逆有償化が進み, 使用済自動車の不法投棄や不適正処理の増加が懸念されるようになってきた。このようなことから，使 用済自動車のリサイクルの新しい仕組みを構築するための「使用済自動車の再資源化等に関する法律 案」（いわゆる自動車リサイクル法案）が 4 月に国会に提出された。本稿は，その概要を紹介するすの である。

キーワード：使用済自動車の再資源化等に関する法律，自動車リサイクル法，廃棄物処理法，使用済自 動車,リサイクル
\end{abstract}

1.はじめに

わが国においては，年間約 500 万台の使用済自動車が 排出されている。このうち，外国に輸出されるものを除 いた約 400 万台の使用済自動車が解体処理されていると 推計されている。従来は, 解体業者や破砕業者が使用済 自動車から部品や金属など有用資源を回収して，これを 市場で売却するというリサイクルのシステムが有効で あった（わが国における使用済自動車の流れとリサイク ル率の現状については, 図 1 参照。。

しかし, 鉄スクラップ価格の下落や, 最終処分場の ひっ迫等によるリサイクル処理の過程で発生するシュ レッダーダスト (ASR) の処理費用の高騰などによって, 使用済自動車の逆有償化がここ数年で顕著となり, 使用 済自動車の不法投裹や不適正処理の增加が懸念されるよ うになってきた。また，フロン類やエアバッグ等の回収 と適正な処理が求められるようになるなど，使用済自動 車を取り巻く情勢の変化への対応も必要になっている。

原稿受付 2002.5.31

*環境省 溌衰物・リサイクル対策部

自動車リサイクル対策室辰

連絡先： $\mathbf{\top} 100-8975$ 東京都千代田区霞ヶ関 1-2-2
このような情勢に対応するため, 中央環境審議会廃棄 物・リサイクル部会および産業構造審議会環境部会廃棄 物・リサイクル小委員会自動車リサイクルワーキンググ ループにおいて, 使用斉自動車のリサイクルの新しい仕 組み作りについての検討が行われた。

その結果，平成 14 年 3 月に中央環境審議会から「使 用済自動車の再資源化等に関する法律案について」と題 する答申が行われた。また，平成 13 年 9 月には，産業 構造審議会環境部会廃衰物・リサイクル小委員会自動車 リサイクルワーキンググループから第二次報告「新たな 自動車リサイクルシステムの構築に向けて〈自動車リサ イクルに関する制度化に向けた考え方〉」が発表されて いる。

これらの答申・報告を受けて，環境省および経済産業 省においては，使用済自動車のリサイクル制度の法制化 に向けた立案作業を行い，平成 14 年 4 月 12 日に「使用 斉自動車の再資源化等に関する法律案」が閣議決定され， 現在開会中の第 154 回通常国会に提出された。

本稿では, 廃率物処理法とのかかわりにも留意しなが ら,この「使用済自動車の再資源化等に関する法律案」 の概要について略述する。なお, 本法案は本稿の執筆時 点において国会の審議中であるため, 審議の結果を反映 した内容とはなっていないことに注意していただく必要 


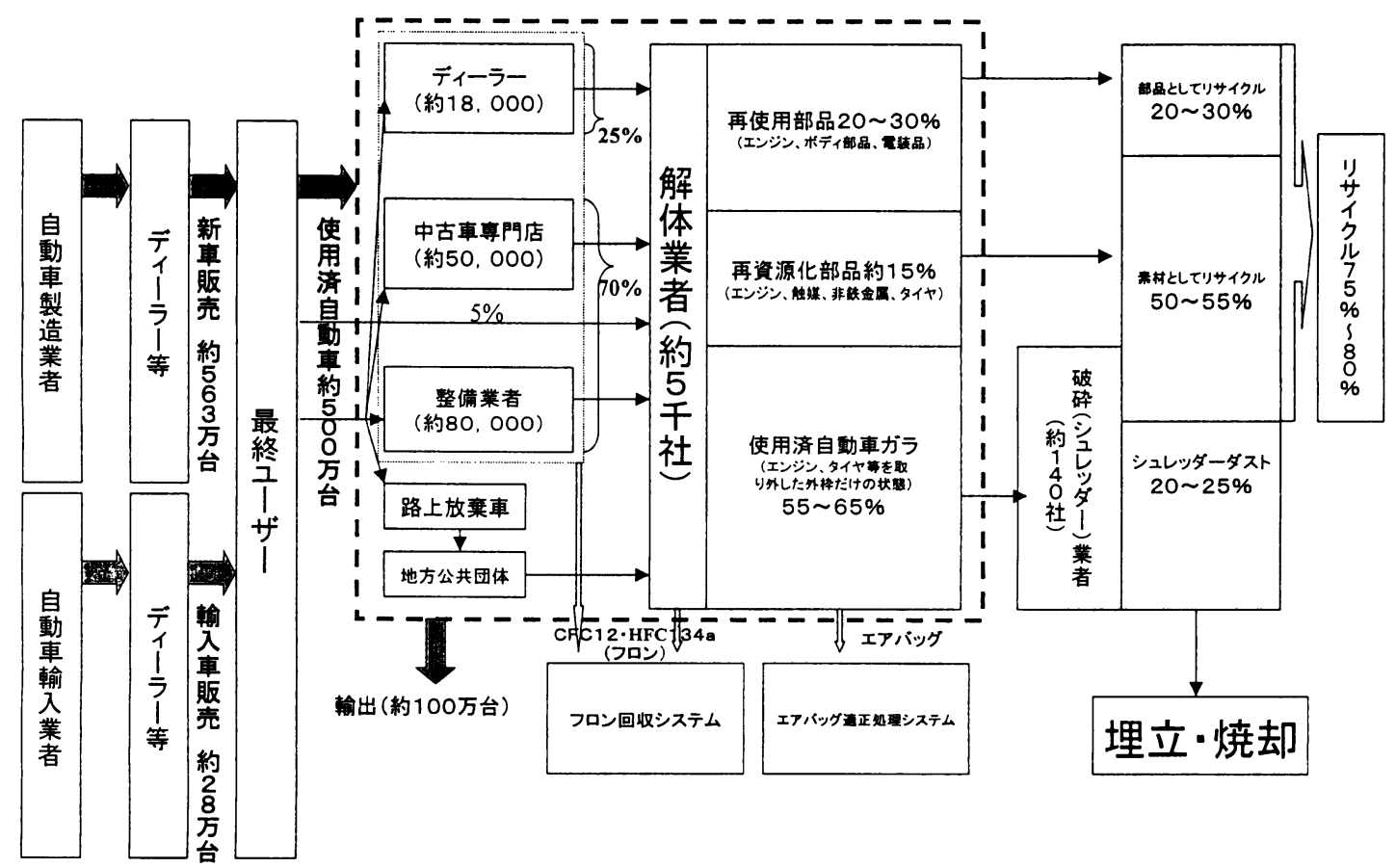

注）ディーラー, 中古車専門店, 整備業者はそれぞれ兼業している場合がある。

図 1 わが国における使用済自動車の流れとリサイクル率の現状

がある。

\section{2. 使用済自動車の再資源化等に関する法律案 の概要（法律案の概念図については，図 2 参照。)}

\section{1 総 則}

(1) 目 的

法律の目的としては,「使用済自動車の引き取り，引 き渡し，再資源化等の適正，円滑な実施のための措置を 講ずることにより，使用済自動車に係る廃棄物の適正な 処理と資源の有効な利用の確保等を図り，もって生活環 境の保全および国民経済の健全な発展に寄与すること」 が掲げられている（法案第 1 条)。すなわち，本法案が 「廃裹物の適正な処理＝生活環境の保全」と「資源の有 効な利用の確保＝国民経済の健全な発展」という 2 方向 の目的を有することが明らかにされている。

\section{(2) 定 義}

法案第 2 条においては，本法案で頻繁に用いられる各 種の用語についての定義規定が設けられている。具体的 には，以下のようになっている。

- 自動車 道路運送車両法第 2 条第 2 項に規定する自 動車（被けん引車, 二輪車, 特殊自動車等を除く）
・使用済自動車 自動車のうちその使用（倉庫等とし ての使用その他運行以外の用途への使用を含む。） を終了したもの

* 中古車として他人に転売された自動車や，自走 できなくなった自動車でも倉庫や物置として活 用されているものは，本法案の対象である使用 済自動車ではない。

・解体自動車 使用済自動車を解体することによって その部品, 材料その他の有用なるのを分離し,これ らを回収した後に残存するすの

* いわゆる「廃車ガラ」のことである。

-特定再資源化物品 自動車破砕残さおよび指定回収 物品

- 特定再資源化等物品 自動車破砕残さ，指定回収物 品およびフロン類

・自動車破砕残さ 解体自動車を破砕し，金属その他 の有用なものを分離し、これらを回収した後の残存 するもの

* 自動車由来のシュレッダーダスト（ASR）の ことである。

- 指定回収物品 自動車に搭載されている物品のうち, 一定の基準を満たすすのとして政令で定めるもの

* 現時点では, 政令ではエアバッグ装置が定めら 


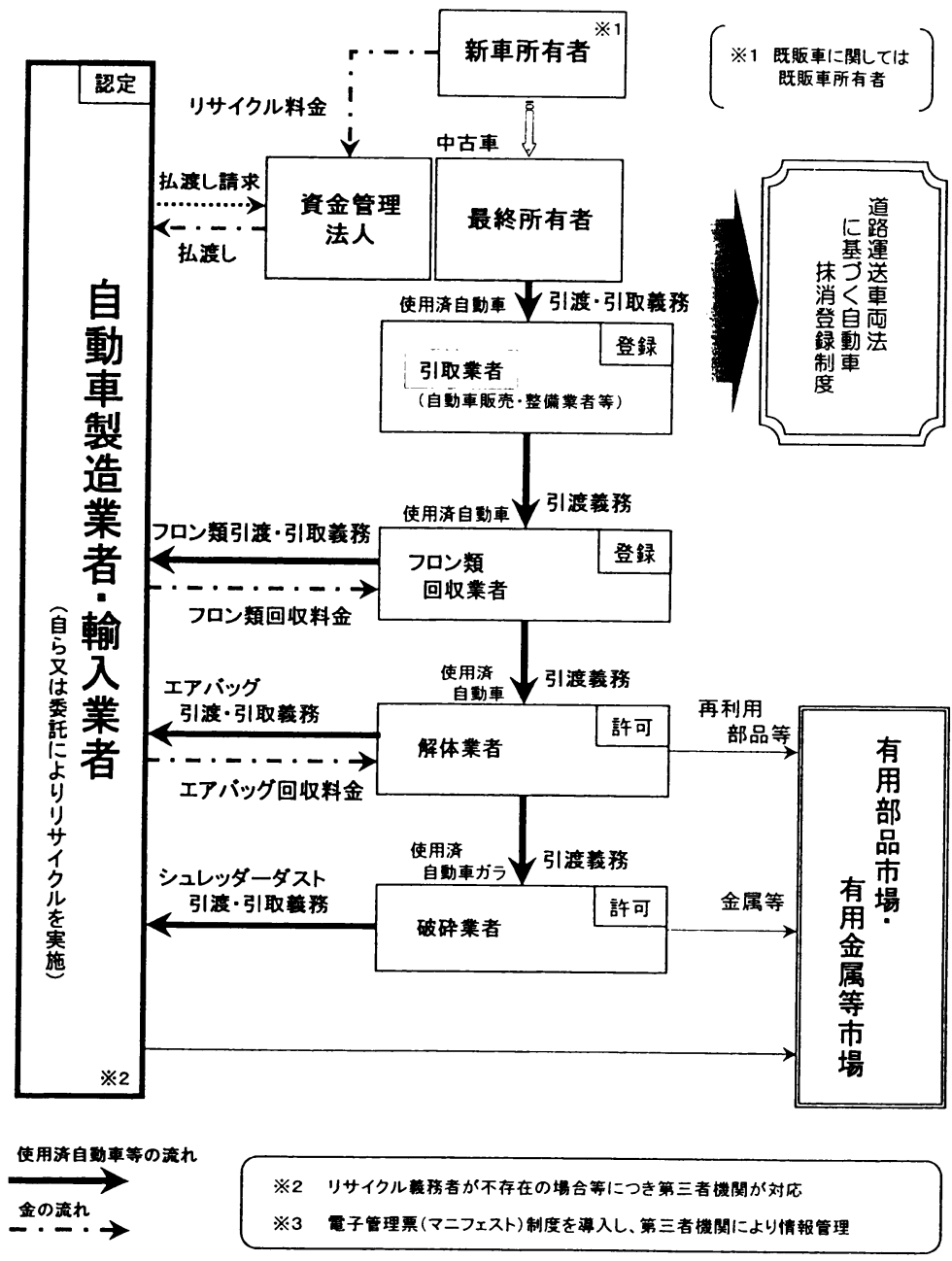

図 2 使用済自動車の再資源化等に関する法律案の概念図

れる予定である。

・フロン類 フロン類回収破壊法第 2 条第 1 項に規定 するフロン類

・特定エアコンディショナー 自動車に搭載されてい るエアコンで, 冷媒としてフロン類が充てんされて いるもの

・再資源化 次に揭げる行為

(1) 使用済自動車等の全部または一部を原材料または製 品の一部として利用することができる状態にする行 為

(2) 使用済自動車等の全部または一部であって燃料の用 に供することができるあのまたはその可能性がある あのを，熱を得ることに利用することができる状態 にする行為

・再資源化等 再資源化およびフロン類の破壊
・引取業 自動車の所有者から使用済自動車の引き取 りを行う事業

* 都道府県知事の登録を受けて引取業を行う者は 「引取業者」と呼ぶ。

・フロン類回収業 使用済自動車に搭載されている特 定エアコンディショナーからフロン類の回収を行う 事業

* 都道府県知事の登録を受けてフロン類回収業を 行う者は「フロン類回収業者」と呼ぶ。

・解体業 使用済自動車または解体自動車の解体を行 う事業

* 都道府県知事の許可を受けて解体業を行う者は 「解体業者」と呼ぶ。

・破砕業 解体自動車の破砕および破砕前処理を行う 事業 
* 都道府県知事の許可を受けて破砕業を行う者は 「破碎業者」と呼ぶ。

「破砕前处理」とは，圧縮その他の主務省令で 定める破砕の前処理をいう。

・自動車製造業者等 自動車の製造等を業として行う 者

*「自動車の製造等」とは，自動車の製造もしく は輸入する行為またはこれを他人に委託する行 為をいう。

・関連事業者 引取業者, フロン類回収業者, 解体業 者および破砕業者

（3）自動車製造業者等の責務

(1) 自動車の設計およびその部品または原材料の種類を 工夫することにより，自動車の長期使用を促進する ととあに, 使用済自動車の再資源化等を容易にし, 費用を低減することに努める。

(2) 関連事業者に対し，自らが製造等をした自動車の構 造に関する情報を適切に提供する等, 再資源化等の 実施に必要な協力をするよう努める。

（4）関連事業者の責務 使用済自動車の再資源化に関 する知識・能力の向上に努める。

（5）自動車の所有者の責務 自動車が使用済自動車と なることを抑制するとともに, 自動車の購入に当 たり再資源化等の実施に配慮して製造されたすの を選択すること等により，使用済自動車の再資源 化等を促進するよう努める。

（6）国の責務 再資源化等に関する国民の理解を深め るとともに，その実施に関する国民の協力を求め るなどの必要な措置を講ずるよう努める。

（7）地方公共団体の責務 国の施策之相まって, 地域 の実情に応じ, 使用済自動車の再資源化等を促進 するよう必要な措置を講ずるよう努める。

\section{2 再資源化等の実施}

(1) 関連事業者による再資源化の実施

(1) 自動車の所有者の義務

自動車の所有者は, 使用済自動車を引取業者に引き渡 さなければならない。

(2)引取業者の義務

引取業者は, 使用済自動車について再資源化預託金等 の預託を確認するとともに, 正当な理由がある場合を除 き,その者から当該使用済自動車を引き取らなければな らない。

当該使用済自動車に特定エアコンディショナーが搭載 されている場合はフロン類回収業者に, それ以外の場合 には解体業者に, それぞれ当該使用済自動車を速やかに
引き渡さなければならない。

(3) フロン類回収業者の義務

フロン類回収業者は, 正当な理由がある場合を除き, 引取業者から使用済自動車を引き取り, 主務省令で定め るフロン類の回収に関する基準に従って特定エアコン ディショナーからフロン類を回収して自動車製造業者等 に引き渡すととあに, 使用済自動車を解体業者に引き渡 さなければならない。

(4) 解体業者の義務

解体業者は, 正当な理由がある場合を除き, 引取業者 またはフロン類回収業者から使用済自動車を引き取らな ければならない。使用済自動車の解体を行うときは, 主 務省令で定める再資源化に関する基準に従って使用済自 動車の再資源化を行うとともに，使用済自動車から指定 回収物品を回収して自動車製造業者等に引き渡し, 解体 自動車を破砕業者等に引き渡さなければならない。

(5) 破砕業者の義務

破碎業者は，正当な理由がある場合を除き，解体業者 から解体自動車を引き取らなければならない。解体自動 車の破碎前処理を行うときは, 主務省令で定める破碎前 処理に関する基準に従って破碎前処理を行うとともに， 自ら当該解体自動車の破砕を行う場合を除き, 当該解体 自動車を他の破砕業者に引き渡さなければならない。解 体自動車の破砕を行うときは，主務省令で定める再資䃇 化に関する基準に従ってその再資源化を行うととあに, 自動車破哗残さを自動車製造業者等に引き渡さなければ ならない。

\section{(6) 勧告および命令}

都道府県知事は引き取り，引き渡し，再資源化に必要 な行為をしない関連事業者に対して，これらをすべき旨 を勧告することができる。勧告を受けた関連事業者が正 当な理由なくこれに従わないときは，当該関連事業者に 対して, 勧告に係る措置をとるべきことを命ずることが できる。

\section{（2）自動車製造業者等による再資源化等の実施 \\ (1) 自動車製造業者等の引取義務}

自動車製造業者等は, フロン類回収業者, 解体業者ま たは破砕業者から自らが製造等をした自動車に係る特定 再資源化等物品の引き取りを求められたときは，正当な 理由がある場合を除き, 指定引取場所において, 当該特 定再資源化等物品を引き取らなければならない。

\section{(2) 引取基準}

自動車製造業者等は, 特定再資源化等物品を引き取る ときの方法, 特定再資源化等物品の性状等についての引 取基準を主務省令で定める基準に従って定めることがで きる。 
(3) フロン類回収料金および指定回収料金

フロン類回収業者または解体業者は, 自動車製造業者 等にフロン類または指定回収物品を引き渡したときは, 当該自動車製造業者等に対し, フロン類回収料金または 指定回収料金の支払いを請求することができる。自動車 製造業者等は, 当該請求があったときは, その求めに応 じてこれらの料金を支払わなければならない。

\section{(4) 自動車製造業者等の再資源化実施義務等}

自動車製造業者等は，特定再資源化物品を引き取った ときは, 遅滞なく, 当該物品の再資源化を行わなければ ならない。また, 自動車製造業者等は, 特定再資源化物 品ごとに主務省令で定める再資源化を実施すべき量に関 する基準に従わなければならない。

(5) 自動車製造業者等のフロン類の破壊義務等

自動車製造業者等は, フロン類を引き取ったときは, 遅滞なく, 当該フロン類の破壊をフロン類回収破壊法に 規定するフロン類破壊業者に委託しなければならない。

（6) 再資源化の認定

自動車製造業者等は, 特定再資源化物品の再資源化を 行おうとするときは, 主務大臣の認定を受けなければな らない。

(7) 解体自動車の全部再資源化の実施の委託に係る認定 自動車製造業者等は, 解体業者または破砕業者に委託 して, 解体自動車の全部再資源化を行おうとするときは, 主務大臣の認定を受けることができる。

* 解体自動車の全部再資源化とは, 解体業者が再 資源化に関する基準に従って再資源化を行った 後の解体自動車を, 国内において主務省令で定 める事業を行う解体自動車全部利用者がその原 材料として利用することができる状態にするも のをいう。この制度は, 解体自動車を電炉に投 入するなどのシュレッダーダストを発生させな い方法で使用済自動車のリサイクルが行われた 場合にも，主務大臣の認定を受けた自動車製造 業者等が, シュレッダーダストを引き取ったと きと同じく再資源化料金の払い渡しを受けられ るようにするための規定である。

(8) 再資源化等に係る料金の公表および勧告等

自動車製造業者等は, 自らが製造等をした自動車に係 る自動車破砕残さ，指定回収物品およびフロン類につい て行う再資源化等に係る料金を当該自動車の販売時まで に定め, 公表しなければならない。

主務大臣は, 自動車製造業者等が公表した再資源化等 に係る料金が適正な原価を著しく超えていると認めると きまたは適正な原価に著しく不足していると認めると きは，当該自動車製造業者等に対し，その料金を変更す
べき旨の勧告をすることができる。当該自動車製造業者 等が正当な理由なくその勧告に係る措置をとらなかった ときは，当該自動車製造業者等に対し，その勧告に係る 措置をとるべきことを命ずることができる。

(9)勧告および命令

主務大臣は, 特定再資源化等物品の引き取りまたは再 資源化等に必要な行為をしない自動車製造業者等がある ときは, 当該自動車製造業者等に対し, 当該行為をすべ き旨の勧告をすることができる。当該自動車製造業者等 が正当な理由なくその勧告に係る措置をとらなかったと きは, 当該自動車製造業者等に対し, その勧告に係る措 置をとるべきことを命ずることができる。

\section{3 登録およひ許可}

(1) 引取業者の登録

引取業を行おうとする者は, 当該業を行おうとする事 業所の所在地を管轄する都道府県知事の登録を受けなけ ればならない。

* 引取業者の登録は 5 年の更新制となる。また, 登録拒否要件として, 所定の欠格要件に該当す る場合や，使用済自動車に搭載されている特定 エアコンディショナーに冷媒としてフロン類が 含まれているかどうかを確認する体制が, 主務 省令で定める基準に適合していないと認められ る場合, 申請書の虚偽記載の場合などが定めら れている。なお，フロン類回収破壊法に基づく 「第二種特定製品引取業者」の登録を受けてい る者は, 自動的に本法案に基づく「引取業者」 として登録を受けた者とみなされる。

（2）フロン類回収業者の登録

フロン類回収業を行おうとする者は, 当該業を行おう とする事業所の所在地を管轄する都道府県知事の登録を 受けなければならない。

* フロン類回収業者の登録は 5 年の更新制となる。 また, 登録拒否要件として, 所定の欠格要件に 該当する場合や，使用済自動車に搭載されてい る特定エアコンディショナーからのフロン類の 回収の用に供する設備の種類および能力が, 主 務省令で定める基準に適合していないと認めら れる場合, 申請書の虚偽記載の場合などが定め られている。なお, フロン類回収破壊法に基づ く「第二種特定製品回収業者」の登録を受けて いる者は, 自動的に本法案に基づく「フロン類 回収業者」として登録を受けた者とみなされる。

（3）解体業者の許可

解体業を行おうとする者は, 当該業を行おうとする事 
業所の所在地を管轄する都道府県知事の許可を受けなけ ればならない。

* 解体業者の許可は 5 年を下らない政令で定める 期間ごとの更新制となる。また，許可の要件と して，その事業を的確かつ継続して行うに足り るあのとして主務省令で定める基準に適合する 施設および能力を有し，かつ，欠格事由に該当 しないと認められるときでなければ許可をして はならないこととされている。また，欠格要件 としては，禁銅以上の刑に処せられて 5 年を経 過しない者や暴力団員などが定められ，廃棄物 処理法に基づく廃棄物処理業の許可の場合之ほ ぼ同様となっている。なお，廃裹物処理業の許 可を受けて解体業を営んでいる者は，一定の期 間内に都道府県知事に届出書を提出すれば，本 法案における解体業の許可を受けたものとみな される。

（4）破碎業者の許可

破砕業を行おうとする者は，当該業を行おうとする事 業所の所在地を管轄する都道府県知事の許可を受けなけ ればならない。

* 破碎業者の許可の更新期間，許可の要件，欠格 要件については，解体業者之同様の規定が定め られている。なお,産業廃棄物処分業の許可を受 けて破碎業を営んでいる者は，一定の期間内に 都道府県知事に届出書を提出すれば，本法案に おける破砕業の許可を受けたものとみなされる。

\section{4 再資源化預託金等}

\section{（1）再資源化預託金の預託義務}

自動車の所有者は, 当該自動車の最初の登録ファイル への登録時までに，当該自動車に係る再資源化等料金に 相当する再資源化等預託金を，資金管理法人に対し預託 しなければならない。

（2）再資源化等預託金の払渡し

自動車製造業者等は, フロン類回収業者，解体業者ま たは破砕業者から特定再資源化等物品を引き取ったとき は，再資源化等預託金であって当該特定再資源化等物品 に係るものについて，資金管理法人に対し，その払い渡 しを請求することができる。

* 自動車製造業者等による再資源化等預託金の払 い渡しの請求に際しては，自らが特定再資源化 等物品を引き取ったことを証する移動報告等を 提出する必要がある。

（3）再資源化預託金等の取戻し

再資源化預託金等が預託されている自動車の所有者は,
当該自動車を輸出した場合その他当該再資源化預託金等 を預託しておく必要がないあのとして政令で定める場合 には，当該再資源化預託金等を取り戻すことができる。

\section{5 移動報告}

\section{（1）移動報告}

関連事業者等は，使用済自動車を引き取ったときまた は引き渡したときは，当該使用済自動車等の車台番号そ の他の事項を情報管理センターに報告しなければならな い。

\section{（2）移動報告の方法}

関連事業者等は，移動報告については，電子情報処理 組織を使用して行わなければならない。

* 移動報告は原則として電子ネットワークを利用 して行わなければならないが，対応できない事 業者については，例外的に所定の手数料を納め て書面で移動報告を行うことも認められる。

（3）勧告および命令

都道府県知事および主務大臣は，関連事業者等が移動 報告等の義務を遵守していないと認めるときは，当該関 連事業者等に対し，必要な措置を講ずべき旨の勧告をす ることができる。当該関連事業者等が正当な理由なくそ の勧告に係る措置をとらなかったときは，当該関連事業 者等に対し，その勧告に係る措置をとるべきことを命ず ることができる。

\section{6 指定法人}

（1）資金管理法人

(1) 主務大臣は，資金管理業務を適正かつ確実に行うこ とができると認められるものを，全国を通じて一個 に限り，資金管理法人として指定することができる。

（2）資金管理法人は，次に揭げる業務を行うものとする。 ・再資源化預託金等の管理を行うこと。

・再資源化預託金等の預託に関する証明を行うこと。

・上記の業務に附帯する業務を行うこと。

（3）資金管理法人には，資金管理業務の実施に関する重 要事項を調查審議等する資金管理業務諮問委員会を 置かなければならないものとし，その委員は，資金 管理法人の代表者が学識経験を有する者および一般 消費者の意見を代表する者のうちから，主務大臣の 認可を受けて任命するものとする。

（2）指定再資源化機関

(1) 主務大臣は，再資源化等業務を適正かつ確実に行う ことができると認められるあのを，全国を通じて一 個に限り，指定再資源化機関として指定することが できる。 
(2) 指定再資源化機関は, 次に掲げる業務を行うものと する。

・規模の小さな自動車製造業者等から委託を受けて, 特定再資源化等物品の再資源化等を行うこと。

・引き取るべき自動車製造業者等が存在しない特定再 資源化等物品の再資源化等を行うこと。

・不法投棄等の引取業者への使用済自動車の引き渡し に支障が生じている離島などの特定地域において, 市町村が運般等を行う場合に, 当該市町村に対して 資金の出えん等の協力を行うこと。

・不法投率された使用済自動車を廃率物処理法に基づ く代執行により撤去する地方公共団体に対し，資金 の出えん等の協力を行うこと。

(3) 指定再資源化機関は, 自動車破砕残さ, 指定回収物 品およびフロン類について行う再資源化等に係る料 金をあらかじめ定め，公表しなければならない。

（3）情報管理センター

(1) 主務大臣は, 情報管理業務を適正かつ確実に行うこ とができると認められるものを, 全国を通じて一個 に限り, 情報管理センターとして指定することがで きる。

（2) 情報管理センターは，次に掲げる業務を行うむのと する。

・報告管理事務を電子情報処理組織により処理するた めに必要な電子計算機その他の機器を使用, および 管理すること。

・報告管理事務を電子情報処理組織により処理するた めに必要なプログラム, ファイルその他の資料を作 成, および保管すること。

・ファイルの記録の保存, ファイルに記録されている 事項を記載した書類等の交付, 都道府県知事への報 告等を行うこと。

\section{7 雑則 (3.で詳述)}

(1) 廃棄物処理法との関係

使用済自動車, 解体自動車および特定再資源化物品に ついては,これらを廃棄物とみなして，この法律に別段 の定めがある場合を除き, 廃裹物処理法の規定を適用す る。

\section{（2）廃裹物処理法の特例}

関連事業者等について, 廃棄物処理法に基づく廃棄物 処理業の許可を不要とする特例等についての規定を設け る。

\section{8 罩 則}

関連事業者の無登録または無許可営業等について必要
な罰則を定める。

\section{9 附 則}

(1) 施行期日

第 1 段階（指定法人の指定等）

公布の日から起算して 6 月を超えない範囲において政

令で定める日

第 2 段階（再資源化等料金，指定引取場所の公表，解体 業・破砕業の許可等)

公布の日から起算して 2 年を超えない範冊において政 令で定める日

第 3 段階（本格施行）

公布の日から起算して 2 年 6 月を超えない範囲におい

て政令で定める日

第 4 段階（国土交通大臣等への預託証明書の提示）

第 3 段階の施行から起算して 1 月を経過した日

(2) その他

自動車重量税の還付制度を創設するための租税特別措 置法の一部改正, カーエアコンからのフロン類回収につ いての規定を本法案に移行させるためのフロン類回収破 壊法の一部改正等を行う。

\section{3. 本法案と廃棄物処理法の関係等について}

\section{1 使用済自動車等を廃棄物とみなすことについて}

使用済自動車については, 自動車破砕残さの処分コス トの高騰と鉄スクラップ価格の低迷, 近年の最終処分場 のひっ迫等による逆有償化の進展により, その多くが廃 菓物に該当するようになった。これに加えて，本法案施 行後には, 特定再資源化物品の再資源化が義務付けられ ることなどにより処理コストが更に上昇することから， 使用済自動車はすべて廃棄物に該当することとなると考 えられる。

一方で，本法案においては，再資源化預託金等をユ一 ザーに預託させるため，使用済自動車は見かけ上おおむ ね有償で取引され，また，自動車破砕残さおよび指定回 収物品は自動車製造業者等に引き取られることから, 使 用済自動車等が廃裹物か否かが見かけ上不明確となる場 合が生じ得る。

廃棄物処理法が廃裹物処理業の許可制や廃裹物処理基 準を定め，不法投率や野外焼却の禁止などの廃裹物の処 理に対する各種の規制を設けている趣旨は，廃棄物の処 理による生活環境の保全上の支障を防止するためである。 また，使用済自動車等は使用を終了し，自動車としての 価值を失った物品であるため，上記のように見かけ上有 償で取引される場合であ粗雑に扱われやすい性質がある 
ことから，生活環境を保全する観点から必要な規制を設 けなければ，通常の廃棄物と同様，その保全に支障を与 えるおそれがある。

したがって，使用済自動車等については，見かけ上有 僅か否かにかかわらず，すべてに対して廃棄物処理法の 規制を及ぼす必要があることから，これをすべて廃棄物 とみなす旨の規定が設けられたすのである。

*「特定再資源化等物品」ではなく「特定再資源 化物品」である点に留意。特定再資源化物品は 特定再資源化等物品からフロン類を除いたもの である。廃棄物処理法では廃衰物は「固形状ま たは液状のもの」に限られている（廃棄物処理 法第 2 条第 1 項）ため, 常温で気体であるフロ ン類はもともと廃衰物処理法にいう廃棄物には 当たらない。したがって，フロン類を含まない 「特定再資源化物品」のみを廃棄物とみなすこ ととしたものである。

* 廃棄物とみなされたすのが一般廃棄物であるか 産業廃乗物であるかについては特に言及してい ない。したがって，通常の廃裹物と同様，それ が廃棄物処理法第 2 条第 4 項の規定に該当すれ ば産業廃棄物であり, それ以外のあのについて は一般廃棄物であることになる。

\section{2 産業廃棄物の委託の基準}

廃裹物処理法においては，排出事業者は自らの責任に おいてその産業廃棄物を適正に処理しなければならない こととされ，他人に委託する場合には一定の基準に従わ なければならない。本法案では，使用済自動車等を排出 した事業者については，これらの義務のうち一部のあの を特定の場合に限って適用除外としている。すなわち, 事業者が最終ユーザーとして使用済自動車を引き渡す場 合，解体業者や破砕業者が解体自動車，指定回収物品ま たは自動車破砤残さを引き渡すなどの場合には，本法案 の規定により引き渡すべき相手 (引取業者, 解体業者, 破碎業者, 自動車製造業者等）に引き渡すことを条件と して, 廃棄物処理法第 12 条第 3 項及び第 4 項の規定の 適用が除外されることとなる。これは，このような場合 には，引渡義務や引取義務を負っている関連事業者に使 用済自動車が引き渡されることによって，使用済自動車 等の確実な移転と再資源化等の実施が確保されているこ となどを踏まえて，本法案の定める制度によって担保さ れている事項については，委託に関する規制の一部を解 除することとしたあのである。

なお，上述の適用除外は，あくまであ本法案に従った 引き取り，引き渡しが実際に行われたことを条件として
認められるあのであり, 本法案の規定に従った引き取り 引き渡しが行われなかった場合（例えば，排出事業者が 使用済自動車を引取業の登録を受けていない者に引き渡 した場合など）には，上記の条件が満たされていないの で，廃裹物処理法第 12 条第 3 項及び第 4 項の規定は引 き続き適用される。

\section{3 産業廃棄物管理票}

産業廃棄物管理票は，事業者が産業廃裹物の処理を委 託する際に，処理業者に管理票を交付し，処理の終了後 に処理業者から処理を終了した旨を記載した管理票の写 しの送付を受けることによって，委託した内容どおりの 適正な処理が行われたことを確認するための制度である。

本法案においては, 前述のとおり, 移動報告の制度が 設けられている。

移動報告の制度により，産業廃棄物たる使用済自動車 等についてもその引き取り, 引き渡し, 再資源化の状況 を把握することができ，また，使用済自動車等の不適正 な引き渡し等による生活環境保全上の支障の防止にあ資 することから，移動報告の機能は廃衰物処理法における 産業廃衰物管理票のそれに相当するあのであるというこ とができる。

このため，本法案では，使用済自動車等を排出した事 業者については，本法案による移動報告が行われるべき 場合に限って，産業廃棄物管理票を交付する義務（廃重 物処理法第 12 条の 3 第 1 項）を適用除外としている。 すなわち，事業者が最終ユーザーとして使用済自動車を 引き渡す場合，解体業者や破砕業者が解体自動車，指定 回収物品または自動車破砕残さを引き渡すなどの場合に は，本法案の規定により引き渡すべき相手（引取業者, 解体業者, 破砕業者, 自動車製造業者等) に引き渡すこ とを条件として, 廃裹物処理法第 12 条の 3 第 1 項の適 用が除外されることとなる。

\section{4 再委託等に関する規制}

関連事業者は，廃裹物収集運搬業の許可を受けないで 使用済自動車等の収集または運搬を業として行うことが できるが，自らは使用済自動車の収集または運搬を行わ ず，第三者にこれを委託する場合ああり得る。このよう な行為は, 関連事業者による収集または運搬の再委託に 相当するものと見ることができる。

\section{(1) 一般廃棄物の場合}

一般廃衰物である使用済自動車の他人への委託に際し ては, 政令で定める基準に従わなければならないことと した。なお，この政令で定める基準としては，「引取業 者等が使用済自動車一般廃棄物の収集または運搬を他人 
に委託する場合には, 廃棄物収集運搬業者等資格のある 者に対して委託しなければならない」などの内容とする ことを予定している。

\section{（2）産業廃棄物の場合}

廃棄物処理業者による産業廃裹物の処理の再委託に関 する規定（廃棄物処理法第 14 条第 10 項）については, 必要な読み替えを行った上で関連事業者にも適用するこ ととした。この結果, 関連事業者は, 政令で定める基準 (産業廃衰物の再委託の基準) に従う場合には, 使用済 自動車産業廃裹物等の運搬を他人に委託することができ ることとなる。なお,この産業廃棄物の再委託の基準 （廃衰物処理法施行令第 6 条の 12）は, 使用済自動車等 については「引取業者等が使用済自動車産業廃棄物また は解体自動車の運搬を他人に委託する場合には, 廃棄物 収集運搬業者等資格のある者に対して委託しなければな らない。」どの内容とする予定である。

なお, 事業者が最終ユーザーとして使用済自動車を引 取業者に引き渡す場合, 解体業者が自ら解体を行った解 体自動車もしくは自ら回収した指定回収物品を破砕業者, 他の解体業者もしくは自動車製造業者等に引き渡す場合, または破砕業者が自ら破砕もしくは破砕前処理を行った 解体自動車もしくは自動車破砕残さを他の破砕業者もし くは自動車製造業者等に引き渡す場合には, 当該使用済 自動車, 解体自動車または特定再資源化物品は, 事業活 動に伴って生じた産業廃棄物であることから，それぞれ の事業者に対しては, 廃棄物処理法による排出事業者責 任が生じることとなる。このため, その運搬を他人に委 託する場合には, 廃裹物処理法第 12 条第 3 項から第 5 項までの規定に従って，廃裹物の運搬を業として行うこ とができる者に委託するとともに, 委託の基準に従う義 務や一般的注意義務が課せられることとなる。

\section{5 措置命令}

\section{（1）一般廃裹物}

不適正な一般廃棄物の処分により生活環境の保全上支 障が生じているときなどには, 市町村長は, 当該不適正 な処分を行った者に措置命令を行うことができるほか, 廃棄物処理法第 7 条第 10 項に違反する再委託により当 該不適正な処分が行われたときは, 違法な再委託者に対 してあ措置命令を行うことができるとされている（廃棄 物処理法第 19 条の 4 )。

一般廃棄物である使用済自動車についても, 不適正な 好分があり, 生活環境の保全上支障が生じているときは, 当該不適正な処分を行った者が廃棄物処理法による市町 村長の措置命令の対象となることは当然である。

また, 関連事業者が一般廃棄物である使用済自動車の
運搬を他人に委託する場合において，本法案に違反する 委託により当該不適正な処分が行われたときは, 市町村 長は, その違法な委託をした関連事業者に対しても廃棄 物処理法に基づく措置命令を行うことができる。これは, 関連事業者は, 廃裹物処理法第 7 条第 10 項に代えて政 令で定める基準に従う義務が課せられているところ，そ の違反は廃棄物処理法第 7 条第 10 項の違反の場合之同 様に取り扱う必要があることから, 市町村長による措置 命令の対象とされているあのである。

\section{（2）産業廃棄物 \\ (1) 処分者等について}

不適正な産業廃裹物廃衰物の処分により生活環境の保 全上支障が生じているときなどには, 都道府県知事は,

(1)当該不適正な処分を行った者, (2)委託の基準, 再委 託の基準等に違反する委託により当該不適正な処分が行 われたときは, 当該違法な委託を行った者（3）当該産 業廃棄物の発生から当該不適正な処分に至るまでの一連 の行程における産業廃棄物管理票に係る義務の違反者が あるときは, 当該違反者, (4) 処分者等に対して違反行 為を要求し, 依頼し, 唆し, または助けた者に対して, 措 置命令を行うことができる（廃裹物処理法第 19 条の 5 )。 産業廃裹物である使用済自動車, 解体自動車, 特定再 資源化物品について不適正な処分があり, 生活環境の保 全上支障が生じているときは, 上記のうち(1) および (2) の者が措置命令の対象となることは当然である。

(2) 委託の基準等に違反する委託を行った者について

本法案の規定に従った使用済自動車等の引き取り, 引 き渡しが行われなかったなどにより, 廃棄物処理法第 12 条第 3 項・第 4 項の規定が適用除外されない場合に おいて,これに違反する委託により当該不適正な好分か 行われたときは, 都道府県知事は, 当該違法な委託を 行った者に対して廃棄物処理法に基づく措置命令を行う ことができる。

また, 関連事業者は, 産業廃棄物である使用済自動車, 解体自動車, 特定再資源化物品の運搬を他人から委託さ れた場合には廃裹物収集運搬業者とみなされ，同項によ り読み替えられた廃棄物処理法第 14 条第 10 項の規定か 適用されることとなり，環境省令で定める場合を除き， 政令で定める基準（再委託の基準）に従って再委託しな ければならないこととなる。したがって,これに違反す る再委託により当該使用済自動車等の不適正な好分が行 われたときは, 都道府県知事は, その違法な再委託をし た関連事業者に対して, 廃裹物処理法に基づく措置命令 を行うことができることとなる（廃栽物処理法第 19 条 の 5 第 1 項第 2 号)。

(3) 移動報告に係る義務に違反した者について 
本法案において移動報告制度が整備されることから， その限りにおいて，産業廃棄物管理票についての規定の 適用を除外している。このため, 産業廃棄物である使用 済自動車等の不適正な処分が行われた場合において，そ れについての移動報告に係る義務について違反者がある ときは，その者を廃裹物処理法第 19 条の 5 第 1 項第 3 号に該当する者とみなすこととした。これにより，都道
府県知事は，当該者に対し廃裹物処理法に基づく措置命 令を行うことができる。これは，移動報告が産業廃棄物 管理票と同様に，廃率物の適正な引き取り，引き渡しの 確保により生活環境保全上の支障の発生を防止する機能 を併せ持っあのであることから，移動報告に係る義務の 違反者は, 産業廃裹物管理票に係る義務の違反者之等し い責任を負うべきものであるからである。

\title{
Outline of Automobile Recycling Law
}

\author{
Tsutomu Sakagawa \\ Chief, Waste Management and Recycling Department, Ministry of Environment \\ (Kasumigaseki, Chiyoda-ku, Tokyo, 100-8975 Japan)
}

\begin{abstract}
There had been an efficient recycling system for the collection of parts and metals by dismantlers and crushers for the 5,000,000 end-of-life vehicles which are discarded every year in Japan. However, due to bad conditions like the price of scrap metal being so low and the cost for getting rid of shredder dust being so high, this process has been going in a backward direction and the price of end-of-life vehicles has dropped. This has unfortunately lead to an increase in illegal abandonment and improper handling of end-of-life vehicles. In order to build a new structure for the recycling of end-of-life vehicles due to these latest conditions, a bill on the recycling of resources, etc. for end-of-life vehicles (known as the Automobile Recycling Law) was submitted to the Diet this April, 2002. This paper introduces the outline of this Law.
\end{abstract}

Key words : End-of-Life Vehicles Recycling Law, Automobile Recycling Law, Waste Management and Public Cleansing Law, ELV, recycling 